\title{
CIRCULARITY AND ENCLOSURES: Metabolizing Waste with the Black Soldier Fly
}

\author{
AMY ZHANG \\ New York University \\ (D) https:// orcid.org/0000-0003-4353-745X
}

In the open-air garage, a caretaker dips her spatula into a plastic bin and starts folding over dirt. Under the fluorescent light, the even soil comes to life. Ms. Lin, who grew up in the local agricultural village beside the field laboratory, is carrying out the daily work of fly-raising. Tiny larvae, a lighter shade of brown than the soil, tumble and squirm over one another reaching for the surface. The action subsides after a few minutes, turning the dirt placid again. Curiosity drives me to disturb the peace, so I ask for permission to stir with the spatula. The soil once again rises with excitement. Ms. Lin cheerfully tells me that the larvae feel insecure when exposed and will always burrow to hide. At this stage, the larva's task is to devour the mixture of organic waste - wet vegetable leaves, fish bones, and other kitchen scraps - that she adds to the soil each day. After continuously feeding for about fourteen days, the larva turns into a pupa encased in a hard, dark brown shell. When the pupae are ready to undergo metamorphosis, they will be transferred to a makeshift arboretum. The fully grown pupa will hatch and emerge in its adult form, a large fly with blue translucent wings, and live out the remainder of the week in the garden, to mate and lay eggs before dying.

CULTURAL ANTHROPOLOGY, Vol. 35, Issue 1, pp. 74-103, ISSN 0886-7356, online ISSN 1548-1360. (C) American Anthropological Association 2020. Cultural Anthropology journal content published since 2014 is freely available to download, save, reproduce, and transmit for noncommercial, scholarly, and educational purposes. Reproduction and transmission of journal content for the above purposes should credit the author and original source. Use, reproduction, or distribution of journal content for commercial purposes requires additional permissions from the American Anthropological Association; please contact permissions@americananthro.org.DOI:10.14506/ca35.1.08 


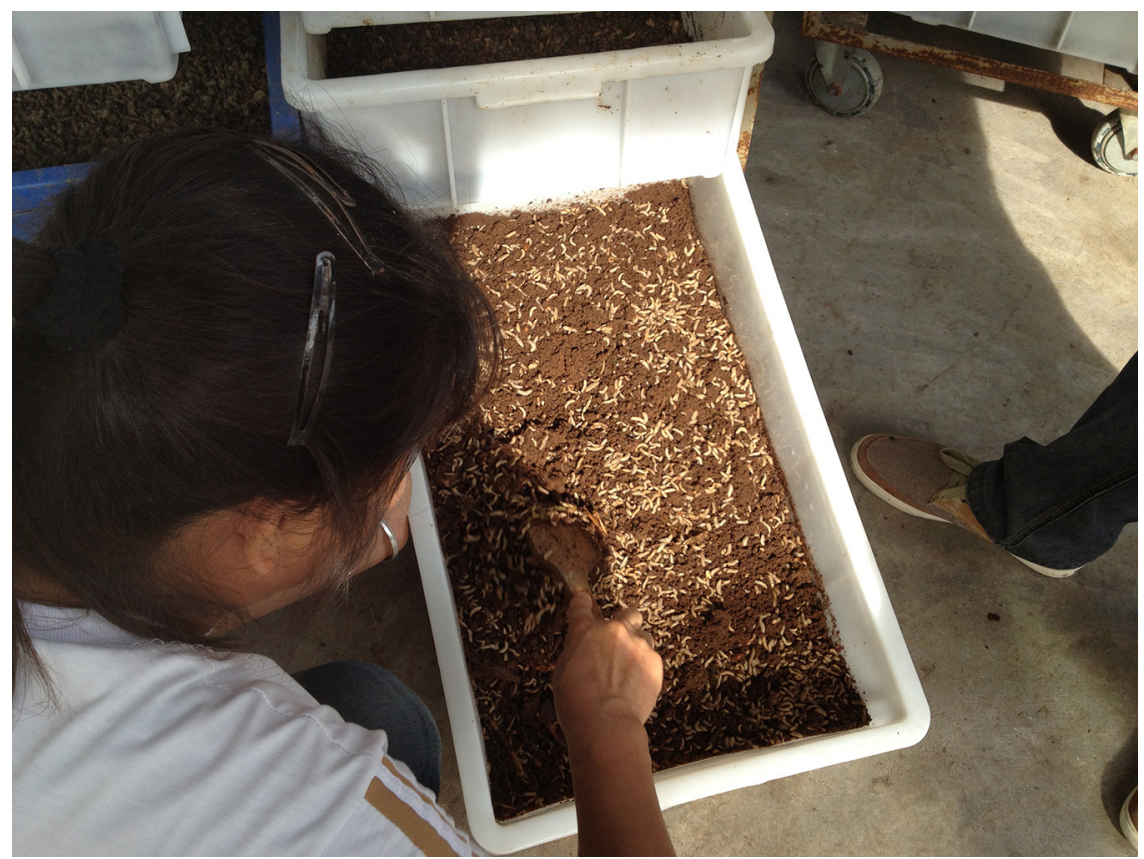

Figure 1. A caretaker stirs a tray of larvae in a Guangzhou field research station. Photo by Amy Zhang.

On this hot and humid evening, I watch as Dr. Wu, the entomologist directing this field laboratory on the edge of Guangzhou, and Ms. Lin, the flies' caretaker, ${ }^{1}$ inspect trays of fly larvae undergoing different stages of growth. As part of a broader effort to construct a modern and sustainable waste-management system, Dr. Wu is attempting to raise larvae toward an experimental project to develop the black soldier fly (Hermetia illucens) as a biotechnology to speed up the treatment of organic waste. A winged insect that originated in the Americas, the black soldier fly (BSF) is now found in most temperate regions of the world. Over the past twenty years, scientists in China and abroad have experimented with ways to transform the BSF into a living technology for organic waste processing. Their expectations rest on the so-called voracious appetite of the fly larvae to devour organic matter, including municipal food waste, slaughterhouse waste, and animal manure. Unlike other breeds of composting worms that are sensitive to fat content, the BSF is lauded for its ability to break down food waste and consume a "Cantonese diet" high in proteins, fats, and salt. Completing the cycle of regeneration, the full-grown larva is further imagined as a protein-rich food source for agricultural feedstock, or even as a nutrition supplement for humans. 
The project captured my attention because it proposed a radically new idea of what counted as a modern solution to waste management in China, a sharp departure from waste-to-energy (WTE) incinerators, the official technology for waste treatment in Guangzhou. Thirty years of urban development and changing consumption and disposal patterns have generated a municipal waste crisis in cities across China. Over the past decade, new policies and programs aimed at environmental remediation have begun to supplement the state's narrow focus on economic development. Since the early 2000s, the Chinese state has pursued a broad range of approaches to waste management guided by the principle of the circular economy (xunhuan jinji), which seeks to achieve, above all, "a circular (closed) flow of materials" by using "raw materials and energy through multiple phases" (Yuan, Bi, and Moriguichi 2006, 5). Under the circular economy, all forms of waste material are imagined as potential sources of value generation. In municipal waste management, this approach has most often translated to investing in WTE incinerators and promoting citizen recycling programs. Such government proposals, however, evaded the question of what to do with the organic waste that constitutes more than 50 percent of the city's total municipal waste stream.

Dr. Wu's experiments with the BSF represent a unique attempt at realizing a key principle of the circular economy by targeting organic waste for continuous circulation into novel forms of value. Specifically, his lab's scientific interventions subject the BSF's bodily processes and life cycle - ingestion, excretion, digestion, growth, reproduction, and death - to temporal modifications meant to match the rhythm and scale of human organic waste output. Scientists like Dr. Wu hope to integrate the BSF's metabolism, reimagined as a tool for environmental remediation and capital generation, into the circulation and transformation of human-generated waste to remedy a dysfunctional urban metabolism. They approach the life cycle of the BSF as a natural or lively infrastructural system, one in which nonhuman labor sustains the organic exchange and circulation of matter and energy (White 1996; Carse 2012; Kirksey 2015; Morita 2017; Hetherington 2019). ${ }^{2}$ Dr. Wu's experiment with the BSF thus seeks to realize the central principles of the circular economy to develop a new biotechnology through the science of entomology. ${ }^{3}$

In the 1970 s, advances in the life sciences coincided with capitalist restructuring to give rise to the so-called biotech revolution, a period of investment in the life sciences (particularly in cellular and molecular biology and genetics) that opened up a new arena for economic growth based on the potential to capitalize on life. Anthropologists introduced the concept of biocapital to interrogate the ways that capitalist political economic structures, such as venture capital or new 
regimes of outsourcing, shape knowledge production within the technosciences. In the life sciences, the appropriation of biological life processes such as reproduction and growth repeat traditional forms of exploitation and extraction (Franklin and Lock 2003; Sunder Rajan 2006; Roosth 2017), ${ }^{4}$ rehearsing a tendency in capitalism to predicate accumulation on the appropriation of the reproductive capacities of life (Vora 2015). In agriculture and food production, for example, scientists and farmers have long imagined animals, plants, and other living substances as producers of value. A range of husbandry practices, including capture, domestication, and breeding, transform a living organism's biological processes into profit-generating mechanisms (Franklin 2007; Landecker 2007; Russell 2010).

Animals and plants are increasingly regarded as effective ecological "workers," their natural proclivities a salve to climate change and ecological crisis (cf. Helmreich 2007; Besky and Blanchette 2018; Hetherington 2019). Consider, for example, how mangroves are used as protection against storm surges (Vaughn 2017), or how an oyster bed is planted to clean up an oil spill (Olson 2018). In keeping with a broader valorization of the assumed lively agency of microbial life in regenerative processes, nature's capacity to facilitate decay or decomposition has increasingly become viewed as fundamental, inevitable, and (therefore) good (Paxson 2013; Jasarevic 2015). Noting that insects and microorganisms facilitate the breakdown of waste, forming lively multispecies assemblages and aggregate on landfills and composting sites (Hird 2013; Reno 2016), scientists like Dr. Wu have shown increasing interest in capturing the latent power or metabolic labor of microorganisms, insects, bacteria, and fungi for environmental restoration. Metabolic labor describes how an animal's vital functions-i.e., growth and reproduction - are targeted to reliably produce value in excess of human inputs (labor and technology) (Beldo 2017; Barua 2018).

Such biotech experiments alter the concept and processes of life itself as bodies and life processes (both human and animal) become new sites of intervention (Haraway 1991; Braun 2007). Metabolic labor is reminiscent of what Jason W. Moore $(2015,54)$ identifies as capital's repertoire of strategies to appropriate nature's unpaid work and energy for the production of surplus value. Anna Lowenhaupt Tsing $(2015,65)$, however, points to the specific terms under which capitalism appropriates nature across a range of cultural contexts; diverse, culturally situated logics enable what she calls "salvage capitalism," when capital takes "advantage of value produced without capitalist control." Similarly, ethnographies of biotechnology reveal that a range of cultural logics and imperatives shape the meaning of life. Biocapital manifests in "particular, incongruent manners in dif- 
ferent locales," embedded within and enabled by different belief systems and values, such as "salvation" or nationalism (Sunder Rajan 2006, 232). Stefan Helmreich (2008, 474) asks, “must capital . . be the sign under which all of today's encounters of the economic with the biological . . . travel"? What alternative economic, cultural, social, and symbolic systems also condition the transformation of biological processes for human purposes?

In an effort to devise a biotechnology to treat organic waste in Chinese cities, scientists are attempting to reconfigure the life cycle of the BSF in accordance with the dominant cultural logics of an ecological, modern vision for waste management. Specifically, my ethnographic work with Dr. Wu reveals how a principle of urban waste management, circularity, and a spatial logic of urban living, enclosures, condition the scientific intervention that promises to harness animal metabolic labor as a biotechnology and a waste infrastructure that can be adapted to the urban ecologies of Guangzhou. In the lab, scientists work to develop optimized breeding techniques to calibrate biological life cycles to the scale and rhythm of urban waste output based on an imagined ideal of how waste might circulate both in the soil and in the city. In an effort to actualize his biotechnology in Chinese cities, Dr. Wu worked persistently to devise an "enclosed" apparatus for adapting his flies to a sanitized urban aesthetic and a now dominant form of urban living. The enclosure, a dominant way of imagining urban space and environmental relations, circumscribes human and nonhuman ecologies and delineates human relations to waste and insects.

As ideologies with broad currency in contemporary China that shape thinking about cities, modernity, and the environment, circularity and enclosure each naturalize a techno-utopian imaginary and render the extraction of human and nonhuman labor invisible. In its ideal form, seen through the lens of circularity and enclosure, the BSF project appears to achieve the ideals of the circular economy as an automated, natural recycling system in which nature's vital capacity becomes endowed with the ability to repair damaged urban ecologies and to sustain the reproduction of urban life. Yet as my ethnographic research in Dr. Wu's laboratory reveals, the practice of aligning animal metabolism with urban metabolism is anything but natural or automatic. Instead, not only does the alignment rely on the constant care for flies by human workers but it also conscripts insects as nonhuman waste workers by reconfiguring their metabolism to urban modes of human living. Moreover, and more surprisingly, efforts to build an automated, self-sustaining, and enclosed biotech apparatus obscure the intimacies that develop between laboring humans and the flies in their care, while the experiments carried out 
in Dr. Wu's lab generate the potential to forge ecological connections with other forms of life in a moment of mutual vulnerability.

Efforts to realize the logics of circularity and enclosures as manifested in the BSF project illustrate the unacknowledged labor practices, both human and nonhuman, and ecological relations that undergird China's pursuit of a modern approach to waste management. Studies of anthropogenic environments such as industrial sites, burned fields, and the cracks of sidewalks point to the often cosmopolitan, unexpected, and unruly encounters that can take place between humans and nonhumans (Tsing 2015; Stoetzer 2018). Yet the project of integrating the BSF into cities reveals a different relation of cohabitation in China's green urbanism. While humans are keen to capitalize on the biophysical processes of nonhuman life, the sanitized aesthetic of modern eco-cities demands that animal life, particularly insects and pests, be expelled or alternatively contained in enclosures.

I begin this article with an account of the development of the circular economy framework for approaching waste management in China, explaining the circular economy's preference for WTE incineration as well as the challenges posed to it by the waste stream in Guangzhou. Next, I juxtapose the genealogy and uses of the concepts of metabolic labor and urban metabolism to understand ecological crisis under capitalism as well as attempts to use biological processes as remediation technologies. Then, turning to the work of the field station, I illustrate ethnographically how, while scientific discourse emphasizes the fly's natural capacity to repair the urban metabolism and to generate value, laboratory experimentations require scientific and care work to erase the seasonal variation in the fly's growth and reproductive cycles to ensure a continuous rhythm of reproduction matched to the tempos and rhythms of urban waste. I then show how Dr. Wu's attempt to realize the principles of the circular economy by creating an enclosed apparatus reflects the aesthetic demands of China's green urbanism. Together, circularity and enclosure, as guiding logics of waste management in Chinese ecological modernization, uphold a fiction of biocapital; they create the illusion that nature generates value and remediates environments without human intervention while mystifying and naturalizing the appropriation of nature and labor in the new green city.

\section{TOWARD AN ECOLOGICAL, MODERN APPROACH TO URBAN WASTE}

After two decades of annual double-digit growth, the natural environment in China has borne the heavy cost of the nation's economic miracle. In the early 2000s, China explicitly adopted ecological modernization as an official response to 
the crisis of environmental degradation. Ecological modernization first emerged as an approach to environmental sustainability in the early 1980s in western European nations such as Denmark and Germany (Mol and Sonnenfeld 2000). Encompassing a wide range of top-down environmental policy and planning tools that marry environmental concerns with economic development, ecological modernization perpetuates a "gospel of eco-efficiency" (Martínez-Alier 2002). Since the early 2000s, China has adopted a strand of ecological modernization theory that emphasizes technological innovation as a model of development that can simultaneously achieve environmental improvement and maintain continued levels of growth (Lei Zhang, Mol, and Sonnenfeld 2007). ${ }^{5}$ Waste management constituted one of the strategy's key targets. Early attempts to reform industrial waste management included programs to discover new uses for scraps, the building of eco-industrial parks, and subsidies for the recycling sector (Lei Zhang, Mol, and Sonnenfeld 2007). Unlike more critical approaches to waste that advocate a shift away from capitalist modes of production or a slowdown in consumption, the circular economy as manifested in China is fundamentally fixated on devising technological solutions to discover more efficient uses for waste.

When it comes to municipal waste, the state sanctioned and prescribed the use of WTE incineration as part of the circular economy policy. Marketed as a form of clean and green waste technology, WTE incinerators burn trash to generate electricity, offering an apparent seamless conversion between waste and energy. The central state's support for WTE incineration speaks to a preference for large technological facilities that eliminate the need for complicated schemes to sort waste according to different types of materials. However, as citizens began to raise concerns over toxic emissions released from burning mixed waste without adequate environmental oversight, organized protests against WTE incineration sprung up all over China and became particularly heated in Guangzhou (A. Zhang 2014). Citizens pointed out that large amounts of organic waste posed a critical challenge to waste management strategies in the city. Left unsorted, organic matter, making up more than 50 percent of the municipal stream, creates problems during all phases of waste collection. Vegetable peels and kitchen scraps rot in stairwells and leak during transportation. More important, waste that is heavy in organics lowers the temperature of incinerators, thereby decreasing the efficiency and compromising the safety of burning. The high moisture content of mixed waste in Chinese cities thus undermines the efficacy of the state's decision to rely on WTE incinerators. 
In 2013, during the time of my research in Guangzhou, as the city lacked an infrastructure to sustainably process urban organic waste, both the municipal state and citizens (including critics of WTE incinerators as well as waste entrepreneurs) were undertaking initiatives to identify a suitable treatment technology for organics. The most common forms of organic waste treatment used in the Chinese countryside, composting and biogas facilities, had yet to prove adaptable for cities. The Datianshan composting pilot project, an urban composting facility capable of handling more than a hundred tons of organic waste a day, was quickly losing government support as officials sparred over the economic feasibility of scaling up the process (Huang 2013). In 2012, a food safety scandal over the reuse of gutter oil, where illicit cooking oil collected from sewage drains was reprocessed on a large scale and distributed to restaurants and grocery chains, further generated citizen suspicion over the safety of organic waste reuse (Merrifield 2017).

From dogs in Ottoman Egypt (Mikhail 2013) to critters (rats and flies) today that thrive off of the scraps of human consumption (Benson 2015), organic household waste has long sustained urban animal life. In Chinese cities during the premodern and socialist periods, and even into the early post-reform era, animals living alongside humans constituted an informal organic waste treatment system. Families raised pigs and livestock, and kitchen scraps made up a large part of the animals' diet. On a larger scale, farmers facilitated the integration of urban and rural economies through the practice of collecting hogwash (shaoshui), transporting kitchen waste from Guangzhou's restaurants to farms in the countryside to feed livestock. Animal metabolism thus facilitated exchanges between urban and rural economies. In the post-reform period, however, modernization campaigns in Chinese cities targeted hogwash collection as unsanitary, rural, and backward. Agrarian animals and companion insects that once formed an efficient but informal organic waste technology in cities have been all but evicted (Philo 1995). In the BSF project, as I demonstrate below, entomologists endeavor to reintroduce flies to the city in an appropriately modern, technoscientific form. Scientists work to calibrate the metabolic function to erase the seasonal variation of the reproductive cycle of flies, so that the fly reproductive cycle can continuously process human waste.

\section{METABOLIC PROCESS AS LABOR AND THE CHALLENGE OF URBAN WASTE}

The idea of metabolism emerged from efforts to understand interactions between an organism and its environment. First used by biologists to describe "the totality of the biochemical reactions in a living thing" (Fischer-Kowalski 1998, 62), 
metabolism referred to three types of chemical processes for the circulation and exchange of nutrients and energy: the breakdown of food or nutrients to form new building blocks and energy (catabolism), the building up of tissues (anabolism), and the regulatory mechanisms that govern these intricate systems (Beck, Liem, and Simpson 1991). Among ecologists, metabolism describes biochemical processes not just within a single organism but in interactions on the level of systems, so that metabolic interactions capture the cycling of nutrients between organisms as one animal's waste becomes another's food (Fischer-Kowalski 1998, 63). Natural and social scientists use metabolism to describe nature's capacity for self-regulation. Human ecologists, finally, adopted a homeostatic vision of the cycling of nutrients and energy that ostensibly derived from nature, modeling their understanding of energy and labor exchange between society and environment on "natural interactions" (Rappaport 2000).

Famously, Karl Marx employed the notion of metabolism to conceptualize two processes related to change and transformation between labor and nature: the production of labor power through the exchange of energy between bodies and the environment, and the emergence of an ecological crisis under capitalism. Metabolism (Stoffwechsel) is central to Marx's theorization of labor and production, where "concrete" labor refers to the physical activity and metabolic interaction that mediates the exchange of energy between human and nature. Marx viewed the human body as "a site of combustion and exchange" that converted energy into "labor power in the service of more life and capital" (Landecker 2013, 223). ${ }^{6}$ For ecological Marxists, capitalism relies on expanding the appropriation of nature's vital processes beyond human bodies (Moore 2015). Animal reproduction and growth represent potential forms of metabolic labor, forces in nature that "capital presupposes but does not itself produce" (Barua 2018). In other words, animal bodies and their metabolic processes constitute "excess" value that capital freely appropriates (Beldo 2017). For instance, the growth and reproductive system of the broiler chicken, bred narrowly and precisely to produce industrial meat (Boyd 2001), constitutes "simultaneously bodily technology and living commodities" (Barua 2018) for the accumulation of capital. Metabolic processes appropriated as labor generate value by "depend[ing] upon non-human vitalities to predictably exceed human inputs to production" (Beldo 2017, 110).

Marxist ecologists use the concept of metabolic rift to describe an environmental crisis that emerged within a capitalist mode of production. Marx interpreted the aggregate of excrement and industrial waste found in cities to be an index of problems created by industrial agriculture (Foster 2000, 163). As John 
Bellamy Foster (2000) argues, a disjuncture emerged in the nineteenth century as the scale of the production and spatial distribution of agricultural goods disrupted the localized nutrient cycle necessary to replenish soils. In other words, industrial production upset the self-restorative capacity of soil by hindering the return of excrement - endowed with nature's latent power for self-restoration - to the site of production. Urbanization further exacerbated the metabolic rift, increasing the scale of waste aggregated in cities (Foster 2000).

Among urban and industrial ecologists, remediation of the metabolic rift targets waste by reconfiguring linear waste flows toward a closed, circular model. In the field of urban sustainability, urban systems and material flows are constructed in analogy to natural ecosystems; studies of "urban metabolism" render the city a complex and heterogeneous but ultimately ordered system (Tansley 1935; Grimm et al. 2000). The closely related discipline of industrial ecology aims to improve urban metabolism by calculating and engineering material life cycles based on patterns found in the natural world, where one organism's waste constitutes another's food (Frosch and Gallopoulos 1989). The concept of a life cycle expressed in such projects, however, does not capture an attempt simply to mirror nature but to devise interventions to regulate and standardize optimal material flows for human systems. Influenced from the outset by metaphors of feedback loops and energy flows, industrial ecologists conceptualized the life cycle as an essentially technical system to be optimized and perfected. ${ }^{7}$

Chinese policy makers explicitly derived the circular economy from industrial ecology; they similarly target waste and material life cycles as the key to improving urban metabolism. The central aims of the circular economy- "to reduce waste, to transform it into a resource, and to detoxify waste [jianliang hua, ziyuan hua, wuhai hua]" - envision a continuous material circulation to optimize systems of material flows by transforming waste into productive matter (Guangzhou Renmin Zhengfu Bangongting Mishu Chu [Guangzhou Municipal Government Secretariat] 2015). The circular economy exhibits a high modernist impulse to extend the capacity to govern by accelerating, regularizing, and standardizing nature (Scott 1998). As an alternative to WTE incineration, the BSF and its metabolism are positioned as an advanced biotechnology with the capacity to neutralize toxic, contaminating, and threatening waste material while simultaneously generating surplus value and facilitating the circulation of waste in the city. In Dr. Wu's project, the insect life cycle and its metabolism are presented as a natural biotechnology for realizing a circular vision of waste transformation for cities in 
which insects and their vital processes are put in service of resolving an urban metabolic rift.

In an effort to realize the mandate of the circular economy, the BSF project draws on the promise of insect metabolism as a self-regulating tool to repair the metabolic rift from urban waste. Yet in doing so, it also appropriates and reconfigures the fly's metabolic nature as an inherent form of labor undergirding the production of value. Metabolic labor, however, as I will demonstrate ethnographically below, should not be read as a description of how biophysical processes produce or constitute value in and of themselves, a tendency Moore $(2015,15)$ refers to as the "metabolic fetish" of green materialism. Biological capacities are not naturally productive, but "become so only in certain relations" (Helmreich 2008, 474). A repertoire of techniques originating from industrial agriculture have rendered metabolic labor - the "reproductive dimensions of cultural and biological life" (Heller 2001, 406) — a site for intensified production and commodification through domestication, breeding, and novel forms of biological engineering (see also Russell 2010). Experimental practices create, routinize, and normalize systems of labor and exchange, even at the level of cellular reproduction (Landecker 2007). At the same time, an understanding of metabolic function as nature's capacity for self-regulation obscures the ways that scientific work and animal labor are appropriated through laboratory practice to realize a vision of perfect circularity.

\section{PRODUCING CIRCULARITY THROUGH LABORATORY WORK}

In 2012-2013, I followed the entomologist Dr. Wu in his then nascent experiments to reintroduce an insect, the BSF, back into cities as a technology for modern urban waste management. ${ }^{8}$ Dr. Wu carried out his work with visible enthusiasm for its great potential, even though at the time no one could be sure of the project's success or acceptance by local governments. Two years later, two of Guangzhou's districts, Huadu and Baiyun, were considering deploying the BSF pilot projects as a part of the city's official waste-management infrastructure to treat between two hundred and four hundred tons of organic waste per day (Liang and Cheng 2015). In the summer of 2018, I returned to the field to discover that while the Huadu and Baiyun district governments had shelved their pilot projects, several scientific startups and NGOs in the city were actively running BSF pilot projects to manage organic waste in local communities.

Back in October 2012, I first encountered the BSF project one afternoon during a meeting I attended while working with a local environmental NGO that was conducting research into alternative treatments for organic waste. I sat in a 
conference room in the Guangdong Entomological Institute, as the institute's director, Dr. Luo, offered the following remarks:

From the beginning, we've designed the BSF as a technology that is useful for solid organic waste management. There are many advantages [to the BSF] compared with conventional composting technologies. BSF uses an insect to process [waste]. This has a higher efficiency than microorganisms. Why? Because the BSF feeds on solid organic waste. The process of BSF feeding on organic waste is not one of decomposition [fenjie], but actually a process of transformation [zhuanhua], one of transforming [organic waste] into animal protein. Insect protein is a high value-added resource [gao fujiaze zhiyuan]. Microorganisms break down and decompose elements into a more simplified [compound], useful only for composting. By using the BSF to treat kitchen waste, once it matures, we can process it into all kinds of useful products. ${ }^{9}$

Luo's description distinguishes the BSF from other forms of organic waste technology, such as composting and biodigesters, which merely break down waste. Instead, by consuming organic waste, metabolizing and incorporating it into its own body, the BSF is endowed with the capacity to convert organics to a value-added resource, namely, a marketable form of animal protein. In Marxist thought, the value added in a product is typically regarded as the addition of (exploited) human labor. Yet in Luo's framing, the fly's natural metabolic processes and life cycle, supposedly unmediated by human labor, produce a value-added product: animal protein from organic waste. Luo's account echoes what Helmreich $(2008,464)$ calls the "double fetishism" common to discourses of biotech boosterism. The double fetish allows biological values to appear "in themselves" by representing biological life as the source of value simply because of their origins in living things, and then by erasing the scientific and human labor that goes into creating biovalue in institutional settings such as laboratories. By emphasizing the natural circularity of the fly life cycle, Luo's discourse reiterates the ways that the BSF is envisioned as fulfilling the goals of the circular economy and, as such, naturalizes the vital power of animals as a source of value addition while obscuring human scientific labor that helps generate and enable these capacities. In Dr. Wu's laboratory practice, scientific and care work seeks to align a natural process - an animal's metabolism, its life cycle — with an industrial vision of the circular economy for an optimal, ecological waste regime. In the laboratory, the realization of 
the vision of circulation hinges on developing strategies to standardize the practice of reproduction, that is, the breeding of fly larvae. ${ }^{10}$

Luo's narrative further obscures the labor of his own researchers, including the repeated attempts and failures of the laboratory experiments focused on the reproductive capacities of the flies that Dr. Wu was devising. The BSF is not only expected to carry out the biological processes of its own life cycle but it must also be made to do so in a standardized and predictable manner so as to process the daily output of a city's organic waste. In effect, the scientific experiments in Dr. Wu's lab are meant to synchronize two life cycles: the reproductive life cycle of flies, and the life cycle of organic waste generated by human activity. The vision informing the BSF project imagines that surplus matter (organic waste) can be turned into a commodifiable surplus population (BSF insects). To realize this vision, the life cycle of the insect — eat, excrete, then die - is rendered interchangeable and interdependent with the flow of materials and nutrients in the city.

Although the BSF project envisions the life cycle of the BSF and the life cycle of organic waste production forming a natural feedback loop, in his laboratory experiments Dr. Wu confronted repeated challenges in automating BSF breeding in a standardized and predictable manner. As Dr. Wu pointed out to me, the key challenge of his system is to devise a method of breeding the BSF that can yield a predictable quantity of flies throughout the changing lighting and temperature conditions of different seasons. Just as attention to the calibration of speed and the nature of circulation proves central to the configuration of production and consumption in late capitalism (Cowen 2014; Duclos, Sánchez Criado, and Nguyen 2017), to be adapted as a biotechnology and a waste infrastructure for cities, the speed and reliable reproduction of fly larvae must complement the predictable rate of human organic waste output.

In his field experimental station, located on a former station owned by the Guangdong Entomological Institute, Dr. Wu and his assistants puzzled over how changing seasons, alternating light quality, humidity, and temperature would alter the timing and rhythm of fly growth and reproduction. The successful reproduction of the BSF required close attention to the condition of the insect at each life stage - egg, larva, pre-pupa, pupa, and adult fly. Each adult BSF will lay up to one thousand eggs that take three days to hatch. The tiny larvae feed continuously for a period of about fourteen days, during which their ability to process waste is at its peak. During this time they grow from a 1-millimeter-long pale golden worm to a dark brown worm with a hardened shell, about 2.5 centimeters long with a mass of 200 milligrams. While the larvae tend to avoid light and will burrow to 
hide, the fully grown pre-pupa crawls out of its food source to look for a dry, dark location. The pupa will emerge as an adult winged insect. Under optimal lighting and temperature conditions, adult flies mate, and the female lays eggs one day later, completing its life cycle.

Dr. Wu's makeshift workshop had a series of trays and shelving units installed along each wall. The workshop remained humid even as large fans hummed in the background circulating intermittent gusts of warm air between two wirefence walls. One wall was lined with a series of freshly constructed gray shelving units, with white plastic water pipes running across the horizontal length of the trays. At each stage of their development, the insects require different temperature, moisture, and lighting conditions, so caretakers observe and cater to the specific conditions of each tray. Each tray demarcated a distinct experimental unit that would allow researchers to monitor and make daily alterations to ensure the optimal condition for the reproductive growth and breeding of the flies. The practices in Dr. Wu's lab mirror what scholars have labeled an "infrastitial" protocol or equipment, one that appears to be routine or boring yet never quite standardized (Kelly and Lezaun 2017).

Along the edges, smeared glue streaks and slight irregularities lent the trays a DIY quality. On the very bottom shelf, in the brown mulch, a few larvae were making their way up the sloped sidings. Dr. Wu told me that he would run water underneath the tray to cool the entire setup in the next batch to ensure better temperature control. At each stage, minute adjustments - more water, moving trays to allow for more air circulation - were made in response to the observed condition of individual batches. Ms. Lin pointed to the pre-pupae in one tray that had made their way from the mulch, their bodies marked by a slight curvature. On the other end of the hall, Lin tipped a watering can into a bed of flat brown soil with BSF larvae hidden beneath to ensure the right amount of moisture.

"This batch is doing extremely well," Lin told me, noting that if the moisture and temperature control were off, the flies would perish. "When they die, they tend to die in batches," she noted. The loss of not only a single fly but a population of flies is equivalent to a system failure to reliably circulate (waste) and output (energy) in a close-looped system. There was a sadness to her description of the death of the larvae, in contrast to the excitement she displayed when she showed off the squirming worms. She explained to me how the previous fall they had found a tray of dead flies after an especially humid evening. Guangzhou's winter months, with temperatures occasionally dipping below $5^{\circ} \mathrm{C}$ in January and February, have proven especially difficult for the survival of the larvae. Sometimes rats got into 


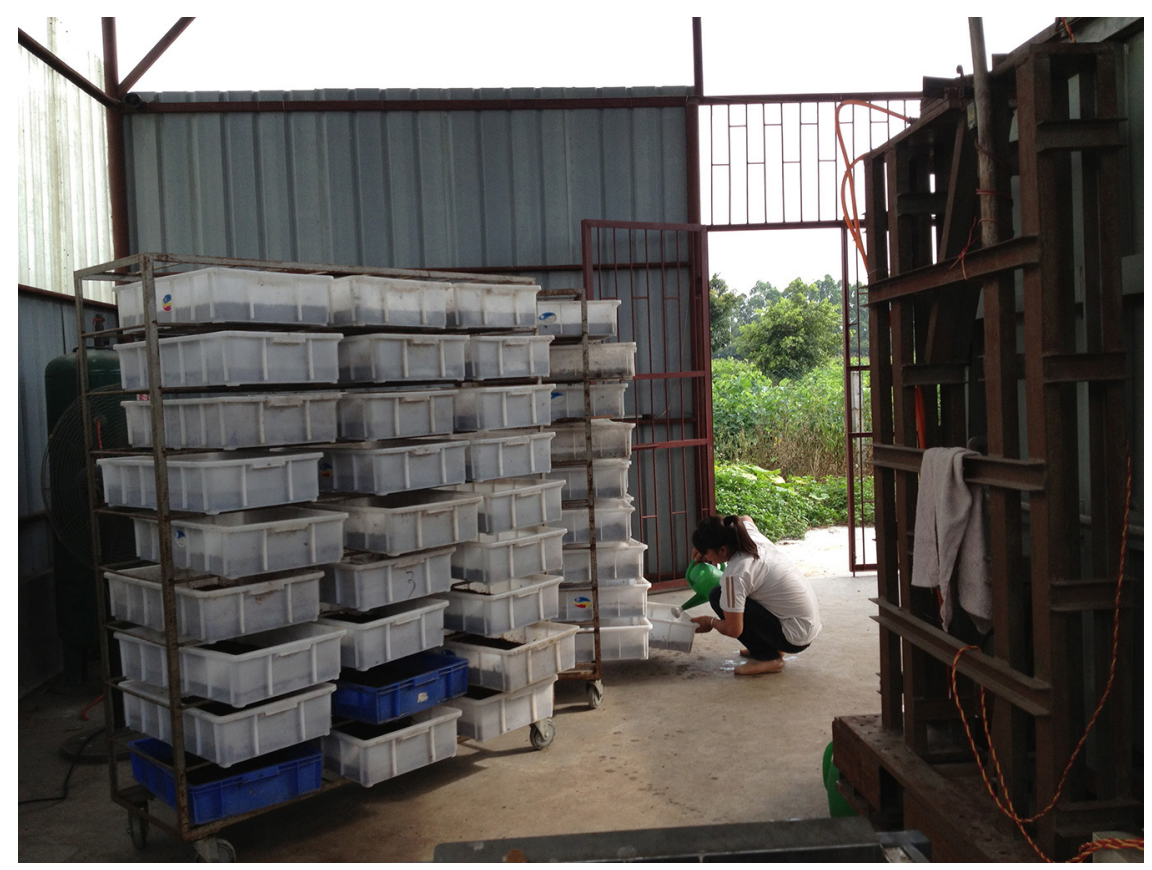

Figure 2. The tray system allows minor adjustments to be made to moisture and temperature during each life stage. Photo by Amy Zhang.

the trays and enjoyed a large feast, hence the cats later seen wandering around the workshop. Whereas in the wild, BSF populations waxed and waned with the changing seasons, in the lab the intimate attentions of an assistant to cultivate and maintain stable conditions enabled the fly population to thrive under varying seasonal conditions.

Guiding me to another series of trays across the workshop, Dr. Wu pointed out that the mulch differs in gradients of darkness depending on the age and life stage of the larvae. Laid out on mesh netting over the top of the tray were larvae that had been hand-collected from the garden, which Dr. Wu had constructed behind the garage to house the adult BSF. From a distance, the yellow splatter of the larvae resembled wet pulp, but up close, the squirming, vibrating movement revealed the contours of worms starting to take shape.

In the garden, a sprinkler system periodically sent a stream of mist into the air. Up to six or seven flies could be found resting on green leaves; bushes were dotted with tiny black speckles. Around the bushes, small black figures buzzed and flashed their blue transparent wings. The larger flies were females carrying eggs. They would pass the last week of their life in the tent where they mated, laid eggs, and then died. Unlike household flies that buzz aggressively around humans, the 


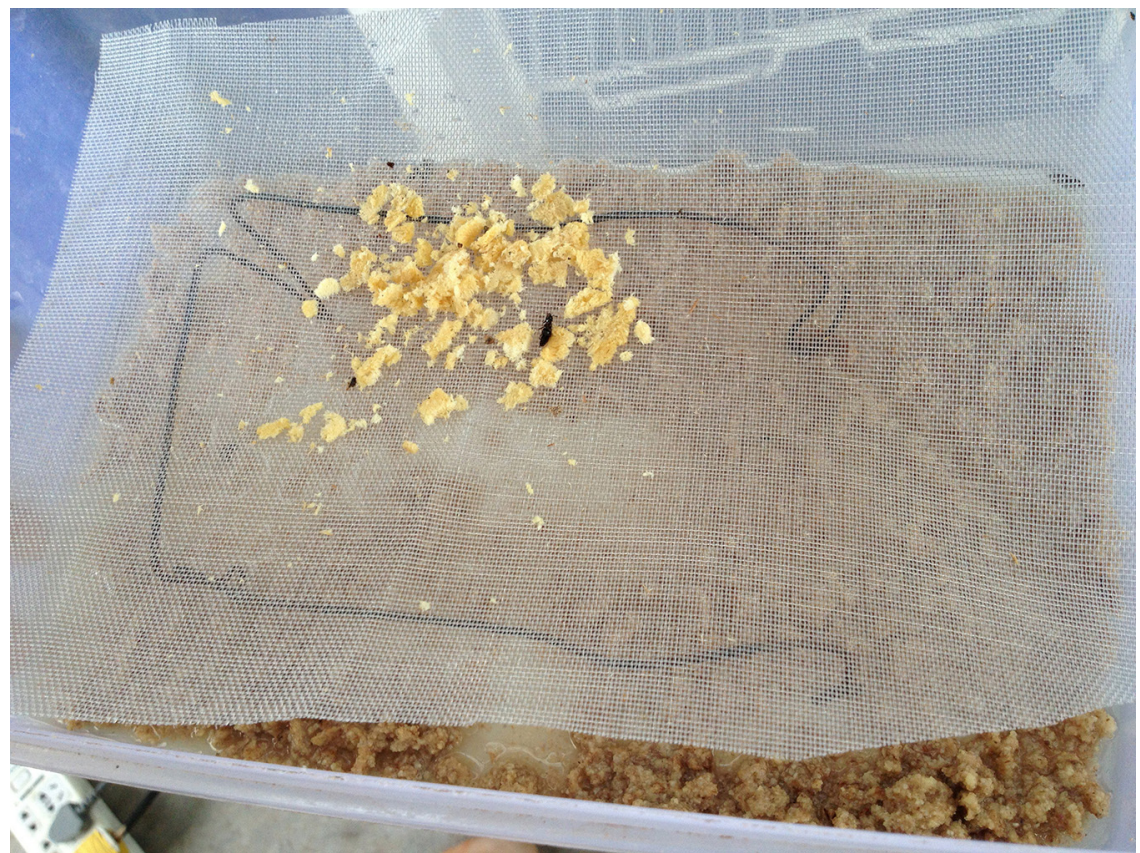

Figure 3. Newly collected black soldier fly eggs. Photo by Amy Zhang.

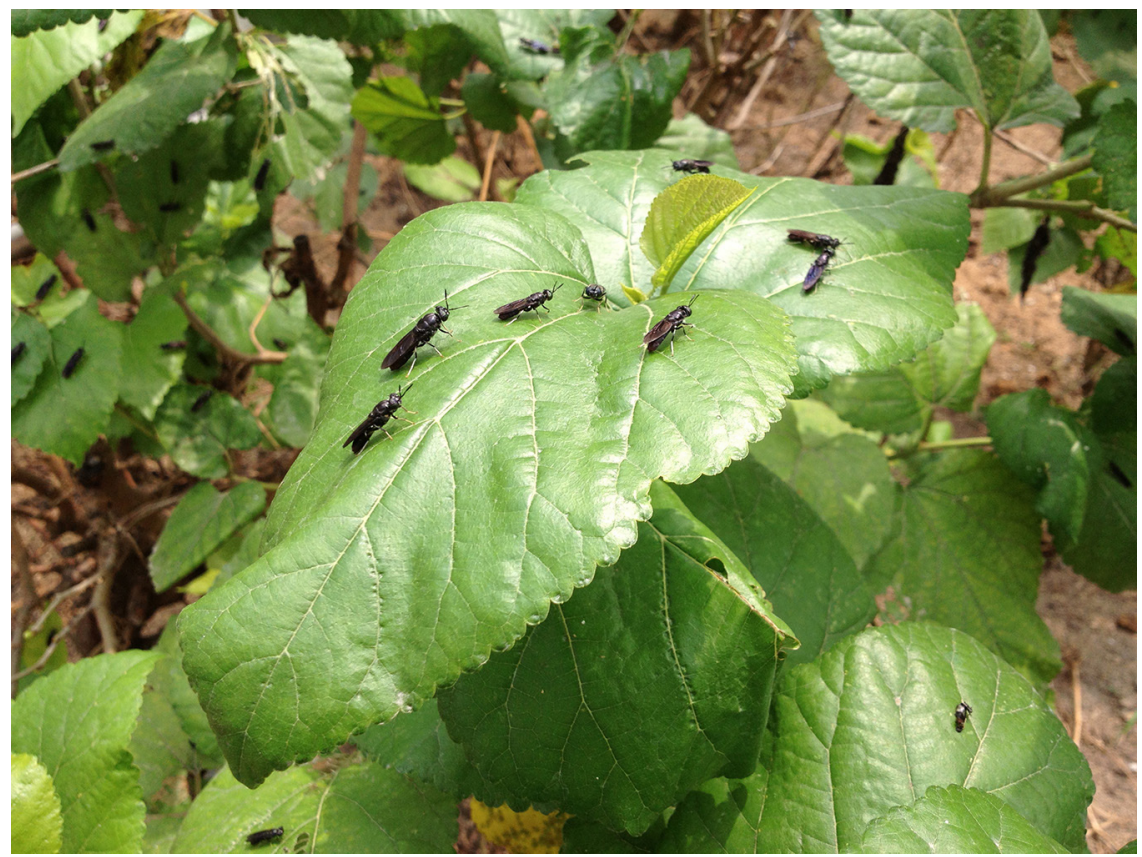

Figure 4. Adult larvae in the last week of their life cycle resting on leaves in the arboretum. Photo by Amy Zhang. 
BSF travels at a more relaxed pace, skirting aimlessly in the air, sometimes landing on our shoulders before jetting off. Dr. Wu described the work of raising the BSF to me:

I have to control the conditions to ensure that the larva grows up healthy. It's just like raising a child, you shouldn't give it anything dangerous to eat, don't let it go to dangerous places. You make sure that they are full, that the environment is under the best temperature control, and it will grow healthily. Now, these controls are all reliant on human labor, and it requires a lot of experience. Once we're finished, we can use machines / technologies [shebei] to control these conditions and they'll be easily passed on.

The minor adjustments made by human laborers to maintain suitable micro-ecologies for insects stand in stark contrast to the vision of an automated system of fly raising, where the production of artificial environmental conditions is meant to be self-sustaining. Instead, the work of raising the BSF reveals a space of dependent cohabitation where new practices of contact and human care and attention prove critical for insect survival. A similar tension between care and control occurs in animal husbandry, where attention to specificities, unpredictability, and embodied practice constitute the human efforts necessary for achieving industrial standardization (Pandian 2008; Singleton 2010; Blanchette 2018). In the BSF project, success in rendering biophysical nature into a reliable infrastructure - mechanized, reliable, and invisible — depends on an intimate relationship between humans and insects. Intimate attention in the lab reveals that techno-utopian dreams of automation and mechanization that eschew the need for labor in the production of value nonetheless rely not merely on human labor but also on forms of care work. In this case, a project to devise an automated breeding machine is conditioned on unacknowledged and willfully obscured physical intimacy and practices of care between humans and insects.

\section{ENCLOSURES OF INSECT REARING AND URBAN LIVING}

The practices of intimate attention to insects I witnessed at the field station are ultimately in service of creating a system to mechanize and standardize fly reproduction within an enclosure. The concept of enclosures has been used to describe two developments in capitalism's strategy of appropriating value from nature: the land-enclosure movements that precipitated the agricultural revolution, and an industrial technique in animal husbandry (Franklin 2007). ${ }^{11}$ In industrial 


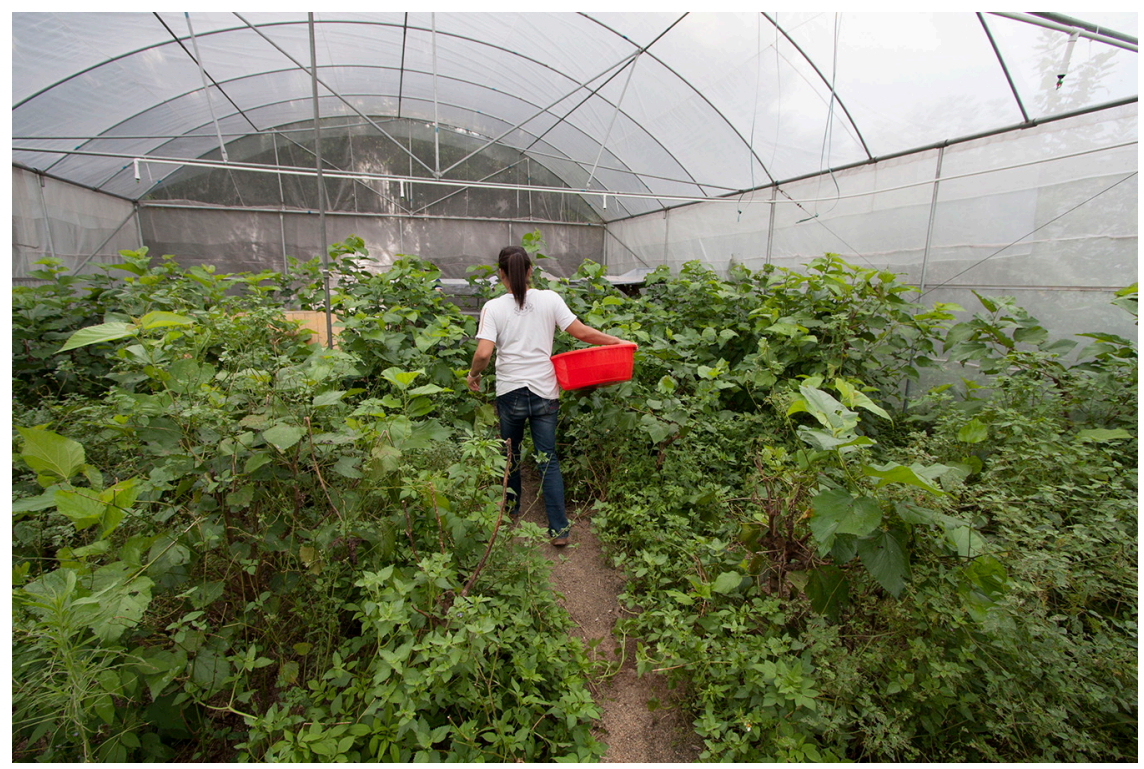

Figure 5. Ms. Lin working in the garden. Photo by Amy Zhang.

husbandry, animal enclosures refer to systems of light and temperature regulation devised to increase animals' rate of growth and reproduction with minimal human engagement (Harrison 2013). As a regulated environment for animal breeding and rearing, the enclosure shifts animal biological functions onto an industrial life cycle.

Dr. Wu's desire to build an enclosed apparatus in effect replicates the strategy of enclosures in industrial husbandry. He hopes to engineer a controlled environment for flies to grow and reproduce with minimal human intervention. Next to the trays of fly larvae sits Dr. Wu's first prototype. The structure-roughly seven feet tall, nine feet wide, and eleven feet deep, made of plastic siding, wood, and metal framing, water pipes and metal screws protruding from its sides - is a defunct machine he remains reluctant to discard. Dr. Wu imagined that organic waste and BSF larvae would be fed into the machine, effectively a black box, ${ }^{12}$ and that it would output adult larvae ready to hatch. The intermediate life stages of the fly were to have taken place entirely inside the machine, the stages of metamorphosis enclosed and obscured. His hope was that he could one day house his box in the garden of any urban community, where workers tasked with performing a minimum level of maintenance would periodically service the machine: adding fly larvae and organic waste and retrieving mature pupae before they turn into adults, thereby circulating fly larvae and organic waste like snacks and coins in and out of a vending machine. 


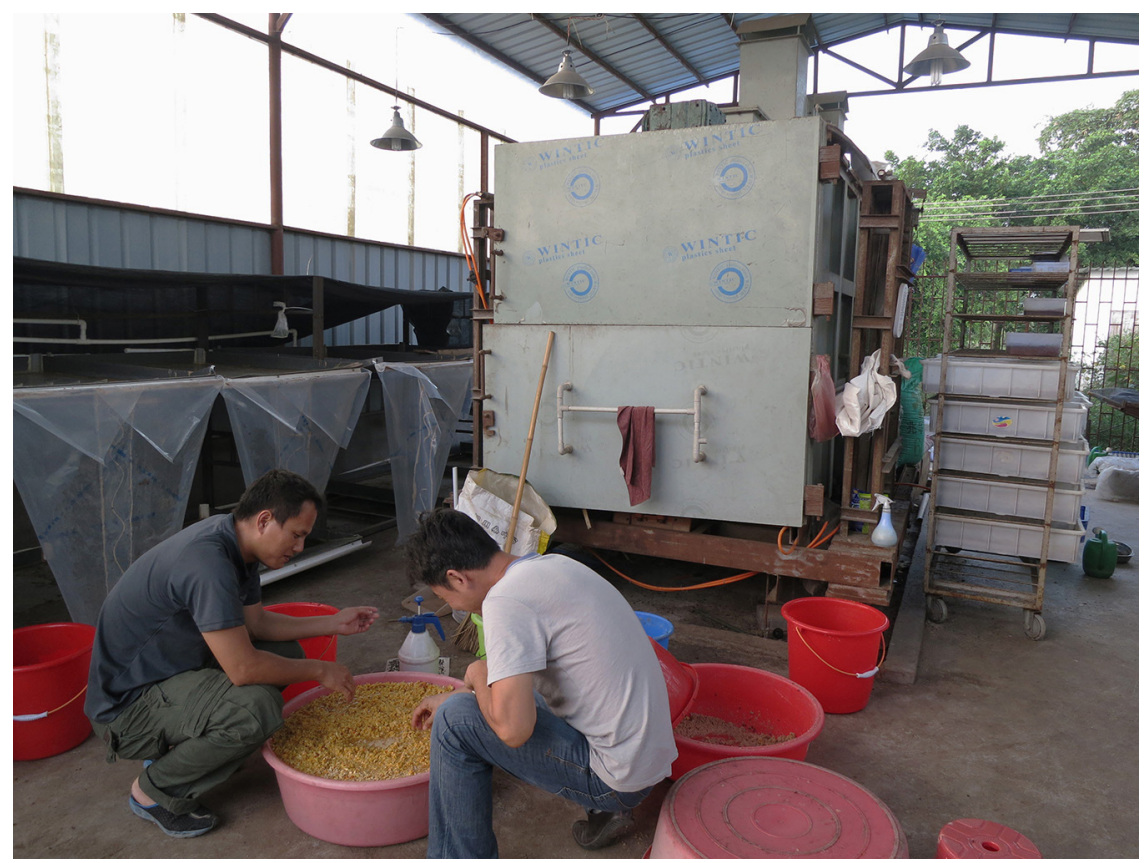

Figure 6. The enclosed prototype for fly rearing. Photo by Amy Zhang.

The enclosure, however, is not only designed to embody the principles of industrial husbandry but also, more important, it manifests the aesthetic, spatial, and environmental ideals of an ecological modern method of urban waste treatment. To turn fly larvae into a waste infrastructure suitable to the urban high-rises of Guangzhou, Dr. Wu tells me, requires an enclosed (fengbishi) system. Throughout my research in Guangzhou, municipal planners and officials repeatedly used the term enclosure (fengbishi) to describe a spatial and aesthetic characteristic. In the concrete and sanitized halls of apartment complexes, making waste management modern means making trash imperceptible. Trash is stored in receptacles, hidden in stairwells, separated from the spaces of daily life. Newly designed fengbishi waste trucks (introduced by the City Management Bureau) enclose waste to conceal odor and the unsightly process of decomposition. Waste labor-whether performed by humans or animals_ _ remains similarly hidden. In windowless basement rooms or utility closets, sanitary workers manually sort recyclables, their labor ensuring the sustainable processing of waste even in the face of failed citizen recycling campaigns (A. Zhang 2019). Dr. Wu's enclosed apparatus similarly shields from view the labor of care that ensures the reproduction of the insect life cycle. In effect, 
modern waste infrastructure must circulate discard invisibly, while nevertheless ensuring that urban services are delivered regularly and sustainably.

The enclosure is a standardized apparatus that matches an aesthetic order of modern living in contemporary China. In its imagined form, the BSF enclosure echoes the gated housing community (fenbishi xiaoqu), a now pervasive spatial form that organizes life in cities. Gated communities manifest a landscape of fear and insecurity (Caldeira 2000; Low 2001). In post-reform China, since the 1990s, enclosed compounds index a desire for a privatized form of living (Tomba 2006). New apartment complexes and suburban compounds offer exclusionary private space through home ownership, the consumption of housing a key means of social distinction (Li Zhang 2010). However, these gated communities also seek to alleviate ecological concerns by reshaping the urban environment according to a sanitized green aesthetic. In newly developed gated communities, aspirations for green living feature prominently. Landscaping and manicured lawns emulate a ruralist ideal (Sze 2015). Gated spaces set apart from the city signify the achievement of a middle-class lifestyle by virtue of being able to extricate oneself from the filthy, crowded, and disorderly elements of urban life. In these new, ostensibly environmentally minded communities, insects and waste, harbingers of disorder and disease, need to be kept at bay. Insect enclosure conceals the cycles of life, growth, metamorphosis and death, the vital processes of animal life that carry out the labor of ecological remediation but are nevertheless out of step with a desire to create a particular sanitized, green-modernist aesthetic of order.

The enclosed apparatus explicitly enacts a spatial separation between insects, waste, and humans in an urban setting. Dr. Wu knew well that the success of his project depended on overcoming a public revulsion for flies (associated with decomposing waste, filth, and danger) and the broad adoption of a new understanding of the BSF as an ecologically useful insect. To establish a different reputation for the BSF, researchers had to take care that an apparatus generating tens of thousands of fly larvae on an industrial scale did not release unpleasant smells or other discharge that might jeopardize the "environmental quality" of the project. By environmental quality, the team refers both to the apparatus's capacity to meet a series of technical standards for pollution and, more important, to the perpetuation of a spatial order that enacts a politics of concealment for vital processes - reproduction, breakdown, and death — associated with disease, unruliness, and the ungovernability of life.

Prompted by fear of disease and environmental contamination, enclosures circumscribe and control multispecies entanglements that prevent forms of care 


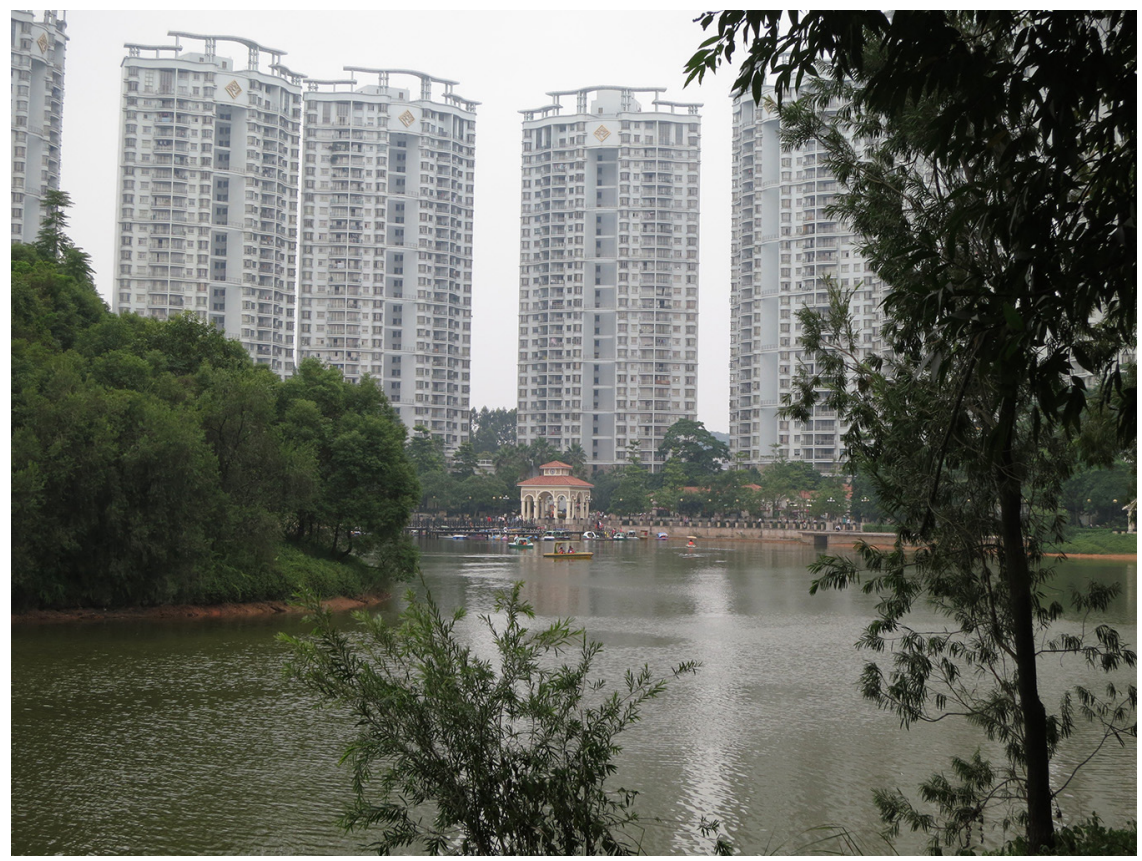

Figure 7. A sanitized, green aesthetic is characteristic of many gated communities in China. Photo by Amy Zhang.

and identification between humans and insects (Law and Mol 2008; Nading 2014; Blanchette 2015; Kirksey 2015). For example, the control of mosquito populations by public health authorities has been characterized as a form of human labor intended to enact interspecies separation and to disentangle relations of cohabitation (Kelly and Lezaun 2014). Sanitation workers target insect breeding grounds (stagnant pools, plants) in the urban landscape and systematically eliminate conditions that facilitate a shared condition of living. In short, biosecurity is founded on a fantasy of "enclos[ing] humans and animals in specific, sterile, and segregated spaces" (Blanchette 2015, 662). In the laboratory, enclosed fly-raising apparatuses entrenched and normalized the capacity to govern the mutability of life through a technical style (Hughes 2012). In the case of urban waste management, enclosures, and the various biological and labor processes they obscure, also facilitate the impression of the achievement of an automated, circular, and ecologically modern vision of waste treatment. In meeting the aesthetic requirements of the modern green city, one that has ejected unruly forms of animal life, the enclosed apparatus further obscures the intimate practices of care and contact between humans and insects that are required to perpetuate the continuous functioning of the circular vision. 


\section{INSECT LABOR AND INTIMACY IN THE ECOLOGICALLY MODERN CITY}

Gabrielle Hecht (2018) suggests that waste, a material index of the catastrophic effects of humanity's existence on the planet's physical and biochemical systems, constitutes the apotheosis of the Anthropocene. In response to its own pressing waste crisis, the Chinese state has adopted a technocentric approach to ecological modernization. Posed as a solution to the waste crisis forged in an era of acute awareness of ecological decline, Dr. Wu's BSF project revives an older agrarian practice of relying on animals to process human waste, yet in accordance with the principles and demands of an ecologically modern city. In doing so, it attempts to manifest an assumption shared by ecological modernization and green urbanism that the shift toward a clean, automated, green city can be readily achieved through the development of new and better technologies (Halpern 2015; Günel 2019).

Despite such pronouncements, as anthropologists have demonstrated, the fulfillment of the most basic urban provisions, particularly throughout the global South, continue to depend on haphazard practices, improvisation, and existing forms of labor and exploitation (Simone 2004; Anand, Gupta, and Appel 2018; Degani 2018). An ecologically modern approach to waste management in China, as elsewhere, obscures the range and depth of work performed by municipal waste workers and informal laborers whose bodies make possible the movement and transformation of matter (Gidwani and Reddy 2011; Fredericks 2018; Doherty and Brown 2019). In Dr. Wu's laboratory, what is obscured includes not only the behind-the-scenes work performed by assistants like Ms. Lin but also the productive harnessing of insects' metabolic and reproductive activity - as if it, too, were labor.

The BSF project, sited at the convergence of biotechnology and China's project of ecological modernization, reveals the fiction of biocapital: the belief that nature itself — absent human intervention, labor, and forms of care work - can generate value and remediate environments. My ethnography of laboratory practice has shown that more complex and nuanced ecological relations between humans and insects are not only obscured but also made possible, even demanded, by efforts to devise biotechnologies to realize green cities in China. And yet, the intimacy between humans and insects required by BSF waste management sits uncomfortably with the expectation that animals be expelled from, or contained and controlled within, modern cities. Here, the apparatus of enclosure, in addition to enabling the BSF biotechnology to capitalize on insects' metabolic and reproductive natures, is designed to fulfill the aesthetic and environmental demand that 
modern cities be rid of undomesticated animals (e.g., through pest control and by removing agrarian animals and slaughterhouses).

The BSF project thus reflects the contradictory demands of contemporary China's ecological urbanism, concerned with sanitization while increasingly reliant on the biological capacities of nonhumans for environmental remediation. As a hoped-for means to resolve this contradiction, the BSF enclosure's attempts to realize ecological modernization in cities not only aim to produce environmental value, they also condition the terms of multispecies cohabitation for humans and insects. The enclosure enacts an interspecies separation that would seem to foreclose possibilities for "a knot of connection" between humans and insects (Govindrajan 2018, 4).

And yet, in carrying out the daily labor practice of scientific work, we see scientists engage in intimate contact with and care for subjects as uncharismatic as flies. In the shadow of the defunct prototype of the enclosure, I briefly glimpsed the intimate appreciation for the vulnerability and potential of nonhuman life: Dr. $\mathrm{Wu}, \mathrm{Ms}$. Lin, and I crouched down around a tray and watched excitedly as the dirt once again turned to life, with hundreds of yellow larvae squirming to the surface.

\begin{abstract}
This essay traces a scientific pilot project to transform the black soldier fly (Hermetia illucens) into a biotechnology to treat urban organic waste in accordance with the dominant cultural logics of an ecologically modern approach to waste management in contemporary China. A principle of urban waste management, circularity, and a spatial logic of urban living, enclosures, condition the scientific intervention that promises to harness animal metabolic labor as a biotechnology and a waste infrastructure that can be adapted to the urban ecologies of Guangzhou. While scientists emphasize the natural proclivities of insect metabolism to transform waste into value, my ethnographic research illustrates that the practice of aligning animal metabolism with urban metabolism is anything but natural or automatic. Together, circularity and enclosure, as guiding logics of waste management in Chinese ecological modernization, uphold a fiction of biocapital; they create the illusion that nature generates value and remediates environments without human intervention while mystifying and naturalizing the appropriation of nature and labor in the new green city. [waste; metabolism; cities; the circular economy; multispecies ethnography; China; urban political ecology; biocapital]
\end{abstract}

\title{
摘要
}

本文研究中国科学家利用黑水虻分解餐厨垃圾生物技术的实验项目。昆 虫学家们希望, 能让这一项目符合中国生态现代化垃圾处理理念, 同时可 
以在现代化封闭式的居住社区中使用。昆虫学家强调, 运用昆虫的代谢系 统来处理餐厨垃圾, 既符合广州城市垃圾设施生态循环化的理念, 也可利 用昆虫的天然生命周期將废物转变成资本。但人类学研究显示, 昆虫的代 谢系統不可能与都市垃圾循环規律自动匹配。在这个项目中, 两个概念一循 环和封闭，仅仅是由生命资本打造生命经济的美好愿望。沒有人的介入， 只根据昆虫自然的生命周期的循环就能产生价值, 这种理论混淆了生物能 与劳动力在发展新型綠色城市中的作用。[垃圾, 代谢系统, 城市, 循环经 济, 多物种民族志, 中国, 都市政治生态学, 生物资本]

\section{NOTES}

Acknowledgments This article would not have been possible without the generosity of Dr. Wu and his team in Guangzhou. Thanks to Paige West and Mark Moritz for their comments, along with Sarah Besky, Ashley Carse, Nicole Peterson, and Maryann Cairns who read this piece as a part of the 2016 Roy Rappaport Prize Committee. Earlier versions of the work benefited from generous readings and comments of Michael Dove, Dana Graef, Bruce Grant, Susan Greenhalgh, Karen Hébert, Emily Martin, Laura Martin, Andrea Muehlebach, Helen Siu, Shivi Sivaramakrishnan, Mei Zhan, Li Zhang, and Ling Zhang. I am grateful to both the previous and current editorial teams of Cultural Anthropology and the anonymous reviewers for their deep engagement and probing questions. Heather Paxson's reiterative edits and incisive comments proved critical for developing the central arguments. D'Arcy Saum read every draft from beginning to end. Versions of the article benefited from the following workshops and presentations: The Environmental History Working Group at Harvard, the Fairbank Center Environments in Asia Lecture series, the Biosocial Network Retreat, and the Center for Urban Environments (University of Toronto Mississauga). Field research was supported by the Wenner-Gren Foundation, the Social Science Research Council, and the National Science Foundation (\#1225886).

1. Ms. Lin, the primary caretaker of the BSF experiment, had no formal scientific training, but she was familiar with animal husbandry. Her work at this field station reflects the reliance of scientific research on agricultural labor typical of field-station research in China and elsewhere (see, e.g., Ann H. Kelly and Javier Lezaun [2017] on the reliance on local villagers for mosquito experiments in Africa).

2. I use the terms infrastructure and biotechnology somewhat interchangeably in this article. In Dr. Wu's project, infrastructures and biotechnology are socionatural systems devised to fulfill the infrastructural function of circulation.

3. See Jake Kosek (2010) for an analysis of the scientific engineering of the honeybee and Hugh Raffles (2010) for a history of insects as both a working animal and a companion species in China.

4. Biocapital has been defined as "form(s) of extraction that involves isolating and mobilizing the primary reproductive agency of specific body parts" (Franklin and Lock 2003, $8)$.

5. See the "China Modernization Report 2007: Study on Ecological Modernization" and the 2008 Circular Economy Law.

6. Ecological Marxists look for concrete labor in sites of metabolic exchange such as agriculture, mining, and fisheries (Howard 2017; Huber 2017).

7. The historical origins and cultural specificities of the concept of the life cycle of things and materials in industrial ecology are rooted not only in biology but also in the principles of machines and information-regulation in cybernetic systems. Key ideas in cybernetics, such as self-regulating nature and energy flows, developed in the decades after the Second World War, precisely when ecology as a discipline was trying to fashion itself after the hard sciences and interested in designing self-regulating machines, such as guided missiles and thermostats (Worster 1994). 
8. The systematic annihilation of insects was first promoted by the sanitation campaigns of the 1950s. Public health campaigns regard the elimination of insects and the removal of waste as critical to the production of healthy bodies and the nation (see Rogaski 2002; Bao 2012).

9. All interview extracts are taken from fieldwork conducted in Guangzhou from 2012 to 2014. Pseudonyms are used.

10. In feminist Marxian terms, production and reproduction are alike as processes of the constant exchange of energy through the body, between humans and nature that undergird labor activity. Capital's production of surplus value relies on this appropriation of unpaid labor in the form of domestic work and biological reproduction (Fortunati 1995; Weeks 2011; Moore 2015; Vora 2015).

11. Enclosing animals forms a critical part of the agro-industrial food production that renders biological processes calculable and controllable. For example, climate-controlled housing is used in rearing poultry to achieve "rapid turnover, high density stocking, a high degree of mechanization, a low labor requirement, and efficient conversion of food into saleable products" (Harrison 2013, 35).

12. In science and technology studies, a black box refers to the closing off of the dynamic and contested process in the formation of scientific knowledge and facts (Latour 1987).

\section{REFERENCES}

Anand, Nikhil, Akhil Gupta, and Hannah Appel, eds.

2018 The Promise of Infrastructure. Durham, N.C.: Duke University Press.

Bao, Maohong

2012 "Environmentalism and Environmental Movements in China since 1949." In $A$ Companion to Global Environmental History, edited by J. R. McNeill and Erin Stewart Mauldin, 474-92. Malden, Mass.: Wiley-Blackwell.

Barua, Maan

2018 "Animal Work: Metabolic, Ecological, Affective." Theorizing the Contemporary, Fieldsights, July 26. https://culanth.org/fieldsights/animal-work-metabolicecological-affective.

Beck, William Samson, Karel F. Liem, and George Gaylord Simpson

1991 Life: An Introduction to Biology. 3rd ed. New York: HarperCollins.

Beldo, Les

2017 “Metabolic Labor: Broiler Chickens and the Exploitation of Vitality.” Environmental Humanities 9, no. 1: 108-28. https://doi.org/10.1215/22011919-3829154.

Benson, Etienne S.

2015 “The Urban Upwelling." American Historian November: 40-44.

Besky, Sarah, and Alex Blanchette

2018 "The Naturalization of Work: Theorizing the Contemporary." Theorizing the Contemporary, Fieldsights, July 26. https://culanth.org/fieldsights/series/thenaturalization-of-work.

Blanchette, Alex

2015 "Herding Species: Biosecurity, Posthuman Labor, and the American Industrial Pig." Cultural Anthropology 30, no. 4: 640-69. https://doi.org/10.14506/ca30.4.09.

2018 "Industrial Meat Production." Annual Review of Anthropology 47, no. 1: 185-99.

Boyd, William https://doi.org/10.1146/annurev-anthro-102317-050206.

2001 "Making Meat: Science, Technology, and American Poultry Production." Technology and Culture 42, no. 4: 631-64. https://www.jstor.org/stable/25147798.

Braun, Bruce

2007 "Biopolitics and the Molecularization of Life." Cultural Geographies 14, no. 1: 6-28. https://doi.org/10.1177\%2F1474474007072817. 
Caldeira, Teresa P. R.

2000 City of Walls: Crime, Segregation, and Citizenship in São Paulo. Berkeley: University of California Press.

Carse, Ashley

2012 "Nature as Infrastructure: Making and Managing the Panama Canal Watershed." Social Studies of Science 42, no. 4: 539-63. https://doi.

Cowen, Deborah org/10.1177\%2F0306312712440166.

2014 The Deadly Life of Logistics: Mapping Violence in Global Trade. Minneapolis: University of Minnesota Press.

Degani, Michael

2018 "Shock Humor: Zaniness and the Freedom of Permanent Improvisation in Urban Tanzania.” Cultural Anthropology 33, no. 3: 473-98. https://doi.org/10.14506/ ca33.3.08.

Doherty, Jacob, and Kate Brown

2019 "Labor Laid Waste: An Introduction to the Special Issue on Waste Work." International Labor and Working-Class History 95: 1-17. https://doi.org/10.1017/ S0147547919000048.

Duclos, Vincent, Tomás Sánchez Criado, and Vinh-Kim Nguyen

2017 "Speed: An Introduction." Cultural Anthropology 32, no. 1: 1-11. https://doi. org/10.14506/ca32.1.01

Fischer-Kowalski, Marina

1998 "Society's Metabolism: The Intellectual History of Materials Flow Analysis, Part 1, 1860-1970.” Journal of Industrial Ecology 2, no. 1: 61-78. https://doi.org/10.1162/ jiec.1998.2.1.61.

Fortunati, Leopoldina

1995 The Arcane of Reproduction: Housework, Prostitution, Labor and Capital. Translated by Hilary Creek. Edited by Jim Fleming. Brooklyn, N.Y.: Autonomedia.

Foster, John Bellamy

2000 Marx's Ecology: Materialism and Nature. New York: Monthly Review.

Franklin, Sarah

2007 Dolly Mixtures: The Remaking of Genealogy. Durham, N.C.: Duke University Press.

Franklin, Sarah, and Margaret Lock

2003 "Animation and Cessation: The Remaking of Life and Death." In Remaking Life and Death: Toward an Anthropology of the Biosciences, edited by Sarah Franklin and Margaret Lock, 3-22. Santa Fe, N.Mex.: School of American Research Press.

Fredericks, Rosalind

2018 Garbage Citizenship: Vital Infrastructures of Labor in Dakar, Senegal. Durham, N.C.: Duke University Press.

Frosch, Robert A., and Nicholas E. Gallopoulos

1989 “Strategies for Manufacturing." Scientific American 261, no. 3: 144-52. https://doi. org/10.1038/scientificamerican0989-144.

Gidwani, Vinay, and Rajyashree N. Reddy

2011 "The Afterlives of 'Waste': Notes from India for a Minor History of Capitalist Surplus." Antipode 43, no. 5: 1625-58. https://doi.org/10.1111/j.14678330.2011.00902.x.

Govindrajan, Radhika

2018 Animal Intimacies: Interspecies Relatedness in India's Central Himalayas. Chicago: University of Chicago Press.

Grimm, Nancy B., J. Morgan Grove, Steward T. A. Pickett, and Charles L. Redman

2000 "Integrated Approaches to Long-Term Studies of Urban Ecological Systems." BioScience 50, no. 7: 571-84. 
Guangzhou Renmin Zhengfu Bangongting Mishu Chu [Guangzhou Municipal Government Secretariat]

2015 "Guangzhou Shi Shenghuo laji fenlei guanli guiding" [Guangzhou Municipal Waste Günel, Gökçe Recycling Policy]. http://www.nanfanghuanjing.com/c2167.html.

2019 Spaceship in the Desert: Energy, Climate Change, and Urban Design in Abu Dhabi. Durham, N.C.: Duke University Press.

Halpern, Orit

2015 Beautiful Data: A History of Vision and Reason since 1945. Durham, N.C.: Duke University Press.

Haraway, Donna J.

1991 Simians, Cyborgs, and Women: The Reinvention of Nature. New York: Routledge.

Harrison, Ruth

2013 Animal Machines. Wallingford, UK: CABI.

Hecht, Gabrielle

2018 "Interscalar Vehicles for an African Anthropocene: On Waste, Temporality, and Violence." Cultural Anthropology 33, no. 1: 109-41. https://doi.org/10.14506/ ca33.1.05.

Heller, Chaia

2001 "McDonald's, MTV and Monsanto: Resisting Biotechnology in the Age of Informational Capital.” In Redesigning Life?: The Worldwide Challenge to Genetic Engineering, edited by Brian Tokar, 405-25. New York: Zed Books.

Helmreich, Stefan

2007 "Blue-Green Capital, Biotechnological Circulation and an Oceanic Imaginary: A Critique of Biopolitical Economy.” BioSocieties 2, no. 3: 287-302. https://doi. org/10.1017/S1745855207005753.

2008 “Species of Biocapital." Science as Culture 17, no. 4: 463-78. https://doi. org/10.1080/09505430802519256.

Hetherington, Kregg, ed.

2019 Infrastructure, Environment, and Life in the Anthropocene. Durham, N.C.: Duke University Press.

Hird, Myra J.

2013 "Waste, Landfills, and an Environmental Ethic of Vulnerability." Ethics and the Environment 18, no. 1: 105-24. https://doi.org/10.2979/ethicsenviro.18.1.105.

Howard, Penny McCall

2017 Environment, Labour and Capitalism at Sea: "Working the Ground" in Scotland. Manchester: Manchester University Press.

Huang, Shaohong

2013 "Datianshan xunhuan yuan canchu laji xiangmu tingchan" [Datianshan Project Halted for Adjustment]. Southern Daily, October 28. http://news.ifeng.com/ Huber, Matthew T. gundong/detail_2013_10/28/30714222_0.shtml.

2017 "Value, Nature, and Labor: A Defense of Marx." Capitalism Nature Socialism 28, no. 1: 39-52. https://doi.org/10.1080/10455752.2016.1271817.

Hughes, Thomas P.

2012 "The Evolution of Large Technological Systems." In The Social Construction of Technological Systems: New Directions in the Sociology and History of Technology, edited by Wiebe E. Bijker, Thomas P. Hughes, and Trevor Pinch, 45-76. Cambridge, Mass.: MIT Press.

Jasarevic, Larisa

2015 "The Thing in a Jar: Mushrooms and Ontological Speculations in Post-Yugoslavia." Cultural Anthropology 30, no. 1: 36-64. https://doi.org/10.14506/ca30.1.04. 
Kelly, Ann H., and Javier Lezaun

2014 "Urban Mosquitoes, Situational Publics, and the Pursuit of Interspecies Separation in Dar Es Salaam.” American Ethnologist 41, no. 2: 368-83. https://doi.org/10.1111/ amet.12081.

2017 "The Wild Indoors: Room-Spaces of Scientific Inquiry." Cultural Anthropology 32, no. 3: 367-98. https://doi.org/10.14506/ca32.3.06.

Kirksey, Eben

2015 Emergent Ecologies. Durham, N.C.: Duke University Press.

Kosek, Jake

2010 "Ecologies of Empire: On the New Uses of the Honeybee." Cultural Anthropology 25, no. 4: 650-78. https://doi.org/10.1111/j.1548-1360.2010.01073.x.

Landecker, Hannah

2007 Culturing Life: How Cells Became Technologies. Cambridge, Mass.: Harvard University Press.

2013 "The Metabolism of Philosophy, in Three Parts." In Dialectic and Paradox: Configurations of the Third in Modernity, edited by Ian Cooper and Bernhard F. Malkmus, 193-224. Bern, Switz.: Peter Lang.

Latour, Bruno

1987 Science in Action: How to Follow Scientists and Engineers through Society. Cambridge, Mass: Harvard University Press.

Law, John, and Annemarie Mol

2008 "Globalisation in Practice: On the Politics of Boiling Pigswill." Geoforum 39, no. 1: 133-43. https://doi.org/10.1016/J.GEOFORUM.2006.08.010.

Liang, Yitao, and Guangwei Cheng

2015 "Huadu shuaixian yang heishuimeng shichi laji" [Huadu the First District to Experiment with Using the Black Soldier Fly to Eat Waste]. YangCheng Evening News, May 21. http://news.sina.com.cn/o/2015-05-21/143931859888.shtml.

Low, Setha M.

2001 "The Edge and the Center: Gated Communities and the Discourse of Urban Fear." American Anthropologist 103, no. 1: 45-58. https://doi.org/10.1525/ aa.2001.103.1.45.

Martínez-Alier, Juan

2002 The Environmentalism of the Poor: A Study of Ecological Conflicts and Valuation. Cheltenham, UK: Edward Elgar.

Merrifield, Caroline

2017 "Spirit, Monster, Table and Tongue." Engagement (blog), Anthropology and Environment Society, A Section of the American Anthropological Association. October 25. https://aesengagement.wordpress.com/2017/10/25/spirit-monster-

Mikhail, Alan table-and-tongue\%.

2013 The Animal in Ottoman Egypt. Oxford: Oxford University Press.

Mol, Arthur P. J., and David A. Sonnenfeld, eds.

2000 Ecological Modernisation around the World: Persectives and Critical Debates. London: Frank Cass.

Moore, Jason W.

2015 Capitalism in the Web of Life: Ecology and the Accumulation of Capital. London: Verso. Morita, Atsuro

2017 "Multispecies Infrastructure: Infrastructural Inversion and Involutionary Entanglements in the Chao Phraya Delta, Thailand." Ethnos 82, no. 4: 738-57. Nading, Alex M. https://doi.org/10.1080/00141844.2015.1119175.

2014 Mosquito Trails: Ecology, Health, and the Politics of Entanglement. Stanford: University of California Press. 
Olson, Valerie

2018 “Oysters: System vs. Infrastructure in the U.S. Gulf Coast Restoration Economy." Paper presented at the Annual Meeting of the American Anthropological Pandian, Anand

Association, San Jose, Calif., November 14-18.

2008 "Pastoral Power in the Postcolony: On the Biopolitics of the Criminal Animal in South India." Cultural Anthropology 23, no. 1: 85-117. https://doi.org/10.1111/

Paxson, Heather j.1548-1360.2008.00004.x.

2013 The Life of Cheese: Crafting Food and Value in America. Stanford: University of California Press.

Philo, Chris

1995 "Animals, Geography, and the City: Notes on Inclusions and Exclusions." Environment and Planning D: Society and Space 13, no. 6: 655-81. https://doi.

Raffles, Hugh org/10.1068\%2Fd130655.

2010 Insectopedia. New York, NY: Pantheon Books.

Rappaport, Roy A.

2000 Pigs for the Ancestors: Ritual in the Ecology of a New Guinea People. Long Grove, Ill.: Waveland Press.

Reno, Joshua O.

2016 Waste Away: Working and Living with a North American Landfill. Oakland: University of California Press.

Rogaski, Ruth

2002 "Nature, Annihilation, and Modernity: China's Korean War Germ-Warfare Experience Reconsidered.” Journal of Asian Studies 61, no. 2: 381-415. http://doi.

Roosth, Sophia org/10.2307/2700295.

2017 Synthetic: How Life Got Made. Chicago: University of Chicago Press.

Russell, Edmund

2010 "Can Organisms Be Technology?" In The Illusory Boundary: Environment and Technology in History, edited by Martin Reuss and Stephen H. Cutcliffe, 249-62.

Scott, James C. Charlottesville: University of Virginia Press.

1998 Seeing Like a State: How Certain Schemes to Improve the Human Condition Have Failed. New Haven, Conn.: Yale University Press.

Simone, AbdouMaliq

2004 For the City Yet to Come: Changing African Life in Four Cities. Durham, N.C.: Duke

Singleton, Vicky University Press.

2010 "Good Farming: Control or Care?" In Care in Practice: On Tinkering in Clinics, Homes and Farms, edited by Annemarie Mol, Ingunn Moser, and Jeannette Pols,

Stoetzer, Bettina 235-56. Bielefield: Transcript.

2018 "Ruderal Ecologies: Rethinking Nature, Migration, and the Urban Landscape in Berlin." Cultural Anthropology 33, no. 2: 295-323. https://doi.org/10.14506/ ca33.2.09.

Sunder Rajan, Kaushik

2006 Biocapital: The Constitution of Postgenomic Life. Durham, N.C.: Duke University Press.

Sze, Julie

2015 Fantasy Islands: Chinese Dreams and Ecological Fears in an Age of Climate Crisis. Oakland: University of California Press. 
Tansley, A. G.

1935 "The Use and Abuse of Vegetational Concepts and Terms." Ecology 16, no. 3: 284

Tomba, Luigi 307. https://doi.org/10.2307/1930070.

2006 Comments on "Contesting Spatial Modernity in Late-Socialist China" by Zhang Li. Current Anthropology 47, no. 3: 480-481. https://doi-org.libproxy.mit. edu/10.1086/503063.

Tsing, Anna Lowenhaupt

2015 The Mushroom at the End of the World: On the Possibility of Life in Capitalist Ruins. Princeton, N.J.: Princeton University Press.

Vaughn, Sarah E.

2017 "Disappearing Mangroves: The Epistemic Politics of Climate Adaptation in Guyana." Cultural Anthropology 32, no. 2: 242-68. https://doi.org/10.14506/ ca32.2.07.

Vora, Kalindi

2015 Life Support: Biocapital and the New History of Outsourced Labor. Minneapolis: University of Minnesota Press.

Weeks, Kathi

2011 The Problem with Work: Feminism, Marxism, Antiwork Politics, and Postwork Imaginaries.

White, Richard

Durham, N.C.: Duke University Press.

1996 The Organic Machine: The Remaking of the Columbia River. New York: Hill and Wang. Worster, Donald

1994 Nature's Economy: A History of Ecological Ideas. Cambridge: Cambridge University Press.

Yuan, Zengwei, Jun Bi, and Yuichi Moriguichi

2006 "The Circular Economy: A New Development Strategy in China." Journal of Industrial Ecology 10, nos. 1-2: 4-8. https://doi.org/10.1162/108819806775545321.

Zhang, Amy

2014 "Rational Resistance: Homeowner Contention against Waste Incineration in Guangzhou." China Perspectives, no. 2014/2: 46-52. http://journals.openedition. org/chinaperspectives/6458.

2019 "Invisible Labouring Bodies: Waste Work as Infrastructure in China." Made in China Journal 4, no. 2: 98-102. https://madeinchinajournal.com/2019/07/23/ invisible-labouring-bodies\%EF\%BB\%BF-waste-work-as-infrastructure-inchina/.

Zhang, Lei, Arthur P. J. Mol, and David A. Sonnenfeld

2007 "The Interpretation of Ecological Modernisation in China." Environmental Politics 16, no. 4: 659-68. https://doi.org/10.1080/09644010701419170.

Zhang, Li

2010 In Search of Paradise: Middle-Class Living in a Chinese Metropolis. Ithaca, N.Y.: Cornell University Press. 